\title{
Size distributions, sources and source areas of water-soluble organic carbon in urban background air
}

\author{
H. Timonen ${ }^{1}$, S. Saarikoski ${ }^{1}$, O. Tolonen-Kivimäki ${ }^{1}$, M. Aurela ${ }^{1}$, K. Saarnio ${ }^{1}$, T. Petäjä ${ }^{2,3}$, P. P. Aalto ${ }^{2}$, M. Kulmala ${ }^{2}$, \\ T. Pakkanen ${ }^{1}$, and R. Hillamo ${ }^{1}$ \\ ${ }^{1}$ Finnish Meteorological Institute, Air Quality, Erik Palménin Aukio 1, P.O. Box 503, 00101 Helsinki, Finland \\ ${ }^{2}$ University of Helsinki, Department of Physical Sciences, P.O. Box 64, 00014 University of Helsinki, Finland \\ ${ }^{3}$ Earth and Sun Systems Laboratory, Atmospheric Chemistry Division National Center for Atmospheric Research, P.O. Box \\ 3000, Boulder, CO 80305-3000, USA
}

Received: 4 January 2008 - Published in Atmos. Chem. Phys. Discuss.: 21 April 2008

Revised: 26 August 2008 - Accepted: 26 August 2008 - Published: 26 September 2008

\begin{abstract}
This paper represents the results of one year long measurement period of the size distributions of watersoluble organic carbon (WSOC), inorganic ions and gravimetric mass of particulate matter. Measurements were done at an urban background station (SMEAR III) by using a micro-orifice uniform deposit impactor (MOUDI). The site is located in northern European boreal region in Helsinki, Finland. The WSOC size distribution measurements were completed with the chemical analysis of inorganic ions, organic carbon (OC) and monosaccharide anhydrides from the filter samples (particle aerodynamic diameter smaller than $\left.1 \mu \mathrm{m}, \mathrm{PM}_{1}\right)$. Gravimetric mass concentration varied during the MOUDI samplings between 3.4 and $55.0 \mu \mathrm{g} \mathrm{m}^{-3}$ and the WSOC concentrations were between 0.3 and $7.4 \mu \mathrm{g} \mathrm{m}^{-3}$. On average, water-soluble particulate organic matter (WSPOM, WSOC multiplied by 1.6 to convert the analyzed carbon mass to organic matter mass) comprised $25 \pm 7.7 \%$ and $7.5 \pm 3.4 \%$ of aerosol $\mathrm{PM}_{1}$ mass and the $\mathrm{PM}_{1-10}$ mass, respectively. Inorganic ions contributed $33 \pm 12 \%$ and $28 \pm 19 \%$ of the analyzed $\mathrm{PM}_{1}$ and $\mathrm{PM}_{1-10}$ aerosol mass.

Five different aerosol categories corresponding to different sources or source areas were identified (long-range transport aerosols, biomass burning aerosols from wild land fires and from small-scale wood combustion, aerosols originating from marine areas and from the clean arctic areas). Categories were identified mainly using levoglucosan concentration level for wood combustion and air mass backward
\end{abstract}

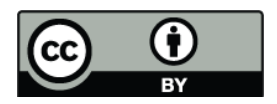

Correspondence to: S. Saarikoski (sanna.saarikoski@fmi.fi) trajectories for other groups. Clear differences in WSOC concentrations and size distributions originating from different sources or source areas were observed, although there are also many other factors which might affect the results. E.g. the local conditions and sources of volatile organic compounds (VOCs) and aerosols as well as various transformation processes are likely to have an impact on the measured aerosol composition. Using the source categories, it was identified that especially the oxidation products of biogenic VOCs in summer had a clear effect on WSOC concentrations.

\section{Introduction}

The thorough knowledge on chemistry of atmospheric aerosol particles is needed to understand the effect of multiphase and multi component aerosol particles on the earth's radiative budget and climate. During the last few years increasing attention has been focused to the carbonaceous fraction consisting of organic carbon (OC) and elemental carbon (EC). OC can be directly emitted to the atmosphere in particulate form and is then called primary organic aerosol (POA) or OC can be formed by gas-to-particle conversion in the atmosphere as secondary organic aerosol (SOA, Kanakidou et al., 2005). SOA formation is a complex process, involving gas-phase oxidation chemistry, partitioning of oxidation products between the gas and particle phases, and aerosol phase chemistry (Weber et al., 2007; Chan et al., 2007).

The organic compounds in atmospheric aerosols can be further divided in water soluble compounds (WSOC) and

Published by Copernicus Publications on behalf of the European Geosciences Union. 
water-insoluble compounds (WISOC). Large fraction of WSOC is assumed to be SOA formed from atmospheric oxidation products of VOCs or via gas-to-particle conversion (e.g. Kondo et al., 2007; Pio et al., 2007). Both processes are generally dependent on the atmospheric conditions like temperature, radiation, photo-oxidants, amount of water vapor and other condensable gases (Fuzzi et al., 2006). According to the results by Decesari et al. (2001) WSOC is composed of highly oxidized species with residual aromatic nuclei and aliphatic chains. WSOC comprises typically $20-70 \%$ of OC (Pio et al., 2007). Smallest WSOC to OC ratios are measured near the combustion sources and larger values are measured for aged aerosol at more remote locations (Pio et al., 2007). Besides SOA, other identified sources or formation mechanisms of WSOC are POA oxidation and e.g. biomass burning, soil particles, aged sea salt and in-cloud processing (Huang et al., 2006).

Particulate water-soluble organic matter is expected to affect the chemical and physical properties of aerosols e.g. hygroscopic behavior (the ability of particles to act as $\mathrm{CCN}$ ), acidity, and radiative properties (Jacobson et al., 2000). Despite the evident significance of OC and WSOC in atmospheric chemistry and physics, information concerning their concentration, size distribution and seasonal variation is limited. Also the sources and formation mechanisms of watersoluble organic compounds are not well known.

The size distributions of WSOC have been already studied in different environments, for example in urban and background areas, coastal site and marine environment (e.g. Li et al., 2000; Yu et al., 2004; Decesari et al., 2005; Turšič et al., 2006). The sampling is often done by using different types of impactors. Several extraction and analytical techniques has been applied to samples. Because there are no standard sampling and analytical procedure, comparison between the results is not straightforward. Long term measurements on the WSOC size distributions are scarce. Matta et al. (2003) have measured the size distributions of WSOC for one year in Po Valley, Italy. To our knowledge, long term measurements of the WSOC size distributions from the northern European boreal region have not been published, although this region has been recognized as one of the most effective emitters of biogenic volatile organic compounds (VOC; Hakola et al., 2003).

This paper presents the results of one year long measurement period for the size distributions of WSOC, ions and gravimetric mass at an urban background station in northern European boreal region in Helsinki, Finland. The WSOC measurements were completed with the chemical analysis of inorganic ions, OC and monosaccharide anhydrides from the filter samples. The goals of this study were to explore the seasonal variation in WSOC size distributions and evaluate the sources of WSOC by using air mass back trajectories and the results of the chemical analyses and the size distributions of WSOC, mass and ions.

\section{Experimental}

\subsection{Measurement site}

The measurements were conducted in Helsinki (Finland) at the urban background station SMEAR III $\left(60^{\circ} 20^{\prime} \mathrm{N}\right.$, $24^{\circ} 97^{\prime} \mathrm{E}, 26 \mathrm{~m}$ a.s.1.). The SMEAR III station is located in the university campus area, $4 \mathrm{~km}$ northeast from the Helsinki city center. About $200 \mathrm{~m}$ from the station there is a busy road. Due to a forest between the measurement site and road the measurement site is not directly exposed to car exhaust emissions.

\subsection{Samples}

The size-segregated samples were collected with a MOUDI from February 2006 to February 2007. The MOUDI was chosen because it has much higher absolute stage pressures than the low pressure impactors. This is expected to reduce though not necessarily eliminate losses of semivolatile organic material. Altogether 45 collections were made throughout the year, 2-7 collections in each month. The duration of each collection was ranging from 24 to $96 \mathrm{~h}$ being typically $72 \mathrm{~h}$. The length of the collection was adjusted according to atmospheric particulate matter mass concentration to avoid overloading or too low mass for chemical analyses. The volume flow rate was $30 \pm 11 \mathrm{~min}^{-1}$. The cut-off diameters (aerodynamic particle diameter corresponding 50\% collection efficiency) of the impactor stages are $0.056,0.100,0.18$, $0.32,0.56,1.00,1.8,3.2$ and $5.6 \mu \mathrm{m}$ (Marple et al., 1991). An inlet with a cut-off diameter of $10 \mu \mathrm{m}$ (Liu and Pui, 1981) was used on the top of the sampling line at about five meters above the ground level.

The MOUDI samples were collected onto 47-mm Alfoil substrates which were washed prior to the sampling with deionized water generated from Milli-Q gradient system with TOC monitor (Millipore Gradient A10). Each substrate set for nine MOUDI stages had three extra Al-foil substrates which served as a blank control. The average blank value was subtracted from the concentrations of each stage. The average WSOC for all the blank Al-foil substrates was $0.21 \pm 0.06 \mu \mathrm{g} \mathrm{C} \mathrm{cm}^{-2}$. The concentrations in the MOUDI stage collecting particles above $5.6 \mu \mathrm{m}$ (highest stage) were about the same as blank values (stage/BL $1.4 \pm 0.4$ ), but for other stages the concentration were on average over threefold of the blank values except for some stages during short 24-h sampling.

The particulate matter (PM) samples particles with an aerodynamic diameter $<1 \mu \mathrm{m}$ were collected using a filter cassette system (Gelman Sciences). The four highest stages of the Berner low pressure impactor (BLPI, Berner and Lürzer, 1980) were used to cut off the particles $>1 \mu \mathrm{m}$ in aerodynamic diameter to achieve the $\mathrm{PM}_{1}$ sample. To collect larger amounts of particulate matter the flow rate of this system was adjusted to $801 \mathrm{~min}^{-1}$. The cut-off diameter 
corresponding to the new flow rate was calculated to be $1 \mu \mathrm{m}$. The sampling duration was typically $24 \mathrm{~h}$ during the working days and $72 \mathrm{~h}$ at the weekends. The samples were collected using two quartz fiber filters (Whatman Q-MA with diameter $47 \mathrm{~mm}$ ) in series. The front filter collects the particulate matter and the back-up filter allows assessing the amount of gaseous species adsorbed on the sampling filter. The back-up filter also collects the compounds evaporated from the front filter, but this cannot be distinguished from the fraction adsorbed from gas phase in the sample flow (Viidanoja et al., 2002; Arp et al., 2007). The $\mathrm{PM}_{1}$ samples were collected from the 9 February 2006 to the end of February 2007, altogether 297 samples. WSOC, OC, monosaccharide anhydrides (MA) and inorganic ions were analyzed from the $\mathrm{PM}_{1}$ samples.

\subsection{Meteorological data}

Local meteorological data were recorded at the SMEAR III station. In order to establish potential source areas of the measured aerosol particles during the measurements, 120-h air mass back trajectories were calculated for the sampling periods using FLEXTRA (Stohl and Wotawa, 1995).

\subsection{Chemical analyses}

\subsubsection{Pretreatment of samples}

The gravimetric mass of the MOUDI substrates was measured prior to and after collection with a Mettler M3 microbalance (Mettler Instrumente AG, Zurich, Switzerland). The relative humidity $(\mathrm{RH})$ and temperature was not controlled, but was recorded for each weighing session. RH had a range of $8-64 \%$, and was most of the time below $40 \%$. For the mass of major inorganic ion at the measurement site, ammonium sulfate, the effect of relative humidity is therefore minor, but the effect cannot be completely ruled out for the total mass. After weighing the samples were stored in a freezer $\left(-20^{\circ} \mathrm{C}\right)$ until analyzed. The MOUDI samples were extracted by shaking the Al-foils with $20 \mathrm{ml}$ of deionized water (Milli-Q, Millipore Gradient A10) for $15 \mathrm{~min}$. Ions and WSOC were analyzed from the same extraction. One $1-\mathrm{cm}^{2}$ piece was cut from the each $\mathrm{PM}_{1}$ filter for the each analytical method (WSOC, MA, OC, and ions). The pieces were extracted by shaking the filter piece with $15 \mathrm{ml}$ (WSOC) or $10 \mathrm{ml}$ (ions) of deionized water for $15 \mathrm{~min}$. After the extraction the samples were filtered using Millex ${ }^{\circledR}$-LCR (pore size $0.45 \mu \mathrm{m}, \emptyset 25 \mathrm{~mm}$ ) for the WSOC analyses, and using the IC Acrodisc syringe filters (pore size $0.45 \mu \mathrm{m}, \varnothing 13 \mathrm{~mm}$ ) for the ion analyses to prevent the quartz fibers to penetrate the sample lines of the carbon analyzer or the ion chromatograph (IC). The filtered (Millex®-LCR, pore size $0.45 \mu \mathrm{m}, \emptyset 25 \mathrm{~mm}$ ) samples subjected to the liquid chromatograph mass spectrometer (LC-MS) for monosaccharide anhydride analyses were extracted to $2 \mathrm{ml}$ of $1: 1$ vol- ume/volume mixture of tetrahydrofuran and deionized water. The extraction was done in an ultrasonic bath for $30 \mathrm{~min}$. In the IC, WSOC and OC analyses both back-up and front filter was analyzed. The result of the back-up filter was subtracted from that in the front filter to correct for the positive artifacts and to subtract the blank values.

\subsubsection{WSOC}

The WSOC was analyzed by the total-organic carbon analyzer TOC- $\mathrm{V}_{\mathrm{CPH}}$ from Shimadzu. The high sensitive catalyst was used to increase the sensitivity of the method. The non-purgeable organic carbon method (NPOC) used in the TOC analyzer has been described in detail by Timonen et al. (2008). Briefly, the sample is extracted to deionized water, which is acidified and injected into an oven. In the oven the carbon is catalytically oxidized to $\mathrm{CO}_{2}$ at $680^{\circ} \mathrm{C}$ and the produced $\mathrm{CO}_{2}$ is detected by a sensitive NDIR-detector. The estimated error of the WSOC results in the MOUDI and $\mathrm{PM}_{1}$ measurements is $15 \%$ for atmospheric concentrations $<2 \mu \mathrm{g} \mathrm{m}^{-3}$ and $10 \%$ for concentrations $>2 \mu \mathrm{g} \mathrm{m}^{-3}$. The main uncertainty in the WSOC analysis is based on the blank in the deionized water used in extraction and in the substrate material.

\subsubsection{Ion Chromatograph (IC)}

The ions $\left(\mathrm{Na}^{+}, \mathrm{NH}_{4}^{+}, \mathrm{K}^{+}, \mathrm{Mg}^{2+}, \mathrm{Ca}^{2+}, \mathrm{Cl}^{-}, \mathrm{NO}_{3}^{-}\right.$, $\mathrm{SO}_{4}^{2-}$, oxalate, succinate and malonate) were analyzed using Dionex DX500 or ICS-3000 ion chromatographs. DX500 had AG11/CG12A guard columns, AS11/CS12A analytical columns, $500 \mu 1 / 300 \mu 1$ loops, ASRS/CSRS ultra II suppressors and $\mathrm{NaOH} / \mathrm{MSA}$ eluent for anions and cations, respectively. The ICS-3000 setup was similar except to anion column (AS17) and the anion eluent (KOH). Based on the test solutions the uncertainty of the IC analysis is in order of 5$10 \%$ for all of the analyzed ions.

\subsubsection{Liquid chromatograph-mass spectrometry (LC-MS)}

The monosaccharide anhydrides (levoglucosan, galactosan and mannosan) were determined by using a LC-MS (Agilent 1100 Series, Trap SL, Agilent Technologies, USA). The used injection volume was $2 \mu \mathrm{l}$ and the eluent was deionized water with a flow rate of $0.1 \mathrm{ml} \mathrm{min}^{-1}$. Two LC-columns were used in series (Atlantis dC18 $3 \mu \mathrm{m}, 2.1 \mathrm{~mm}$ of inner diameter and $150 \mathrm{~mm}$ in length, Waters). A negative electrospray technique was used for ionization. The mass to charge ratio $(\mathrm{m} / \mathrm{z})$ of monitored ion was 161. A similar method has been previously used e.g. by Dye and Yttri (2005).

\subsubsection{Thermal optical carbon analyzer (TOA)}

A thermal-optical carbon analyzer (TOA; Sunset Laboratory Inc., Oregon) was used to determine $\mathrm{OC}$ and $\mathrm{EC}$ from the $\mathrm{PM}_{1}$ samples. The TOA is based on the thermal-optical 
transmittance method (TOT). An optical correction is applied for the separation of pyrolysed OC from EC. The used temperature program was similar to the NIOSH program, except for the last temperature step in the helium phase. The temperature of this last step was decreased from $870^{\circ} \mathrm{C}$ to $800^{\circ} \mathrm{C}$ in order to reduce a premature evolution of EC in the helium mode (Subramanian et al., 2006). Inorganic carbon (carbonate carbon) can in some cases interfere with the determination of $\mathrm{OC}$, since it volatilizes in the helium phase concurrently with OC. However, no carbonate carbon was detected in this study when analyzing the thermograms using the method described in detail by Sillanpää et al. (2005a).

\section{Results and discussion}

3.1 Comparison of WSOC results from the different collection methods

The MOUDI and filter cassette measurements were compared for the subsequent WSOC analyses. Similar analytical procedures were performed for the samples collected in parallel. For the $\mathrm{PM}_{1}$ the cut-size was $1 \mu \mathrm{m}$, and for the MOUDI the WSOC concentration was calculated by adding together the concentrations of the stages with cut-off diameters $\leq 1 \mu \mathrm{m}$. The blank values were subtracted from the WSOC results in the MOUDI. For the $\mathrm{PM}_{1}$ the result of the back-up filter (average $3.1 \pm 0.7 \mu \mathrm{g} \mathrm{C} \mathrm{cm}^{-2}$ ) was subtracted from the result of the front filter to subtract the blank value and estimate the amount of gaseous species adsorbed on the front filter. The average ratios of backup filter to front filter was $0.27 \pm 0.15$ for WSOC. The WSOC results measured from the different substrates are in good agreement with each other. On average the MOUDI $\mathrm{PM}_{1}$ WSOC result was $101 \pm 19 \%$ (average $\pm \mathrm{SD}, n=45$ ) of the corresponding $\mathrm{PM}_{1}$ result. The inorganic ions were also analyzed from the $\mathrm{PM}_{1}$ filters. The measured sulphate concentration for MOUDI samples was $89 \pm 17 \%(n=45)$ of the corresponding $\mathrm{PM}_{1}$ results.

\subsection{Chemical composition of the MOUDI samples}

Altogether 45 MOUDI collections were made between February 2006 and February 2007. The size distributions of gravimetric mass, WSOC and ions were analyzed from the collected MOUDI samples. Figure 1 represents the gravimetric mass, concentration of water-soluble particulate organic matter (WSPOM) $\left(\mu \mathrm{g} \mathrm{m}^{-3}\right)$ and sum of inorganic ions $\left(\mu \mathrm{g} \mathrm{m}^{-3}\right)$ for $\mathrm{PM}_{1}$ and $\mathrm{PM}_{1-10}$ for the MOUDI collections. During the year long measurement the gravimetric mass in MOUDI collections varied between 3.4 and $55.0 \mu \mathrm{g} \mathrm{m}^{-3}$ and the WSOC concentration was between 0.3 and $7.4 \mu \mathrm{g} \mathrm{m}^{-3}$. The measured carbon concentration (WSOC) has to be multiplied by the assumed organic-matter to organic carbon ratio to achieve the amount of water-soluble particulate organic matter. In this study a multiplier of 1.6 has been used following a recommendation by Turpin et al. (2001). On average $25 \pm 7.7 \%$ of the aerosol $\mathrm{PM}_{1}$ mass and $7.5 \pm 3.4 \%$ of the $\mathrm{PM}_{1-10}$ mass comprised of WSPOM. Inorganic ions comprised of $33 \pm 12 \%$ and $28 \pm 19 \%$ of the analyzed $\mathrm{PM}_{1}$ and $\mathrm{PM}_{1-10}$ aerosol mass, respectively. Sulphate and ammonium together contributed on average $81 \pm 12 \%$ and $19 \pm 14 \%$ of the total inorganic ion content in $\mathrm{PM}_{1}$ and $\mathrm{PM}_{1-10}$, respectively. The amount of inorganic ions was typically two times larger than the amount of WSPOM, except during biomass burning episodes when the amount of WSPOM exceeded that of the inorganic ions.

During the measurements two major biomass burning episodes were observed. In the first episode (26 April-6 May 2006), most of the particles were long-range transported from the widespread wild land fires in the western parts of Russia (Saarikoski et al., 2007). During the second episode in summer (1-28 August 2006) most of the particles again originated from wild land fires in Russia, but this time from areas closer to Finland. The episodes had a clear effect on the particulate matter and the WSOC concentrations. The highest values in mass and WSOC in MOUDI collections were measured during the biomass burning episode in spring. The episode conditions are described in more detail by Saarikoski et al. (2006, 2007).

\subsection{Seasonal differences in WSOC concentrations in ultra- fine, fine and coarse particles}

The seasonal variation in the WSOC concentrations in fine particles has been examined in many studies. For urban locations the maximum WSOC concentrations in fine particles has been observed to occur in winter and reach minimum values in summer (Viana et al., 2006; Ho et al., 2006) whereas for marine and mountain sites the highest WSOC concentrations have been measured in summer (Pio et al., 2007; Yoon et al., 2007). This indicates that there might be different sources of WSOC depending of the season and the geographical area.

Recent studies show that biogenic volatile organic compounds emitted by boreal forest might have a large influence to WSOC and OC concentrations in boreal areas (Tunved et al., 2006) when the biogenic activity is high in summer time. To our knowledge, long-term measurements of the WSOC size distributions from the northern European boreal region have not been published. Therefore this study will yield new data on seasonal variations in the particulate organic matter sources in the region.

The average size distributions of WSOC and mass were calculated for winter (December-February, $n=14$ ), spring (March-May, $n=13$ ), summer (June-August, $n=9$ ) and autumn (September-November, $n=9$ ). The WSOC size distributions measured during the biomass burning episode were excluded from the calculations of the average size distributions for each season, since they deviated substantially 


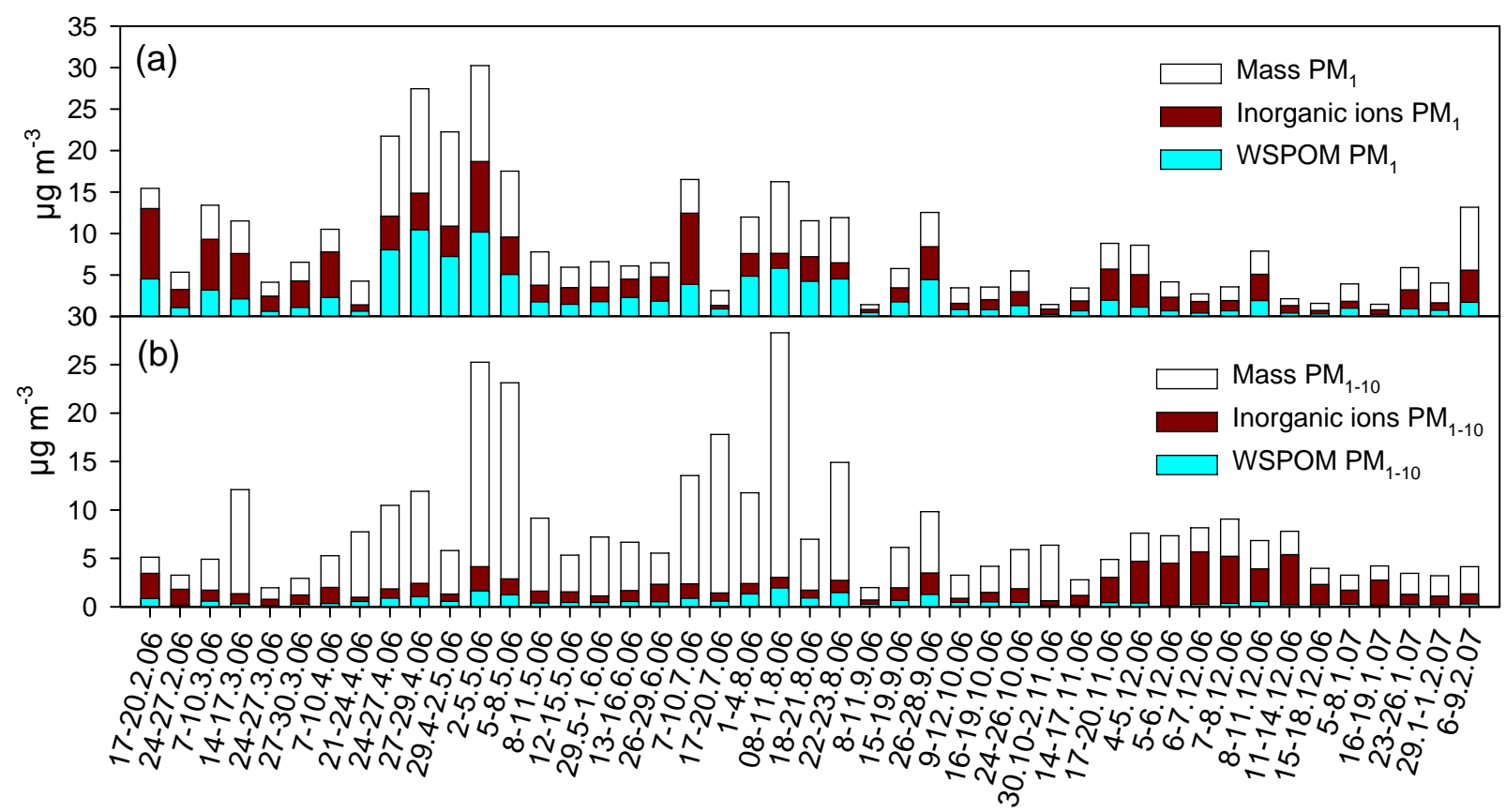

Fig. 1. Concentrations of mass, inorganic ions and WSPOM $\left(\mu \mathrm{g} \mathrm{m}^{-3}\right)$ in $\mathrm{PM}_{1}$ (a) and $\mathrm{PM}_{1-10}$ (b) in the MOUDI collections between February 2006 and February 2007. WSPOM=WSOC multiplied by 1.6.

from the size distributions measured prior to and after the episodes. Despite the changes in the concentrations between the individual collections, the shapes of the size distributions remained quite stable during each season whereas there are clear differences between the seasons. Figure 2 represents the size distributions of gravimetric mass and WSOC in different seasons. The size distributions of the gravimetric mass were bimodal during all seasons. In winter and autumn the mass concentrations were smaller and the shape of size distribution was clearly different when compared to the mass size distributions of spring and summer. For WSOC the dominant mode was typically the accumulation mode between 0.1 and $1 \mu \mathrm{m}$ during all seasons. In winter the concentrations of WSOC were small and since the contribution of the coarse mode $\left(D_{p}>1 \mu \mathrm{m}\right)$ to the WSOC was nonexistent, practically all the WSOC during the winter months resided in the accumulation mode. In spring, summer and autumn the accumulation and the coarse modes were clearly observed in the size distributions of WSOC. In summer and spring more WSOC was observed in ultrafine particles $\left(D_{p}<0.1 \mu \mathrm{m}\right)$ as compared to autumn and winter. Also the accumulation mode $\left(D_{p}=0.1-1 \mu \mathrm{m}\right)$ concentrations of WSOC were substantially larger in summer and spring.

Dicarboxylic acids are most abundant constituents of the organic water-soluble fraction in aerosols (Yao et al., 2002). Oxalate is typically dominating, and contributes $1-3 \%$ of fine mode WSOC (Huang et al., 2006). The size distributions of oxalate (not shown) were in all seasons similar to the size distributions of WSOC in the submicron mode $\left(D_{p}<1 \mu \mathrm{m}\right)$ indicating that the oxalate and WSOC were internally mixed. In the coarse mode the shape of the oxalate size distributions were slightly different from that of the WSOC.

To gauge a relative contribution of the water-soluble particulate matter in the different size classes the average WSPOM/mass ratio was calculated for the each size class for each season (not shown). The ratios for particles above $5.6 \mu \mathrm{m}$ (highest stage) had to exclude from the interpretation because of the relative high blank concentrations of WSOC. The values of other stages were verified to be acceptable. The WSPOM/mass ratio was largest in summer and smallest in winter. It was also observed that the WSPOM/mass ratio was larger in submicrometer particles than in coarse particles. A decrease in the contribution of all carbonaceous species to the particulate mass as the particle size increases has been observed also in other measurements made in urban environments (e.g. Bologna, Matta et al., 2003; and Shenzhen, Huang et al., 2006). A smaller WSPOM/mass ratio in the supermicron particles can be affected by the fact that the mass in large particles is mainly crustal material that is not water-soluble. To further investigate the contribution of WSPOM in the different size classes, an average ratio of WSPOM to inorganic ions was calculated for each season (Fig. 3). The prevailing trend for WSPOM to ions ratio seemed to decreasing with increasing particle size regardless of the season. The highest ratio had particles below $0.1 \mu \mathrm{m}$ and lowest above $1 \mu \mathrm{m}$. Although the standard deviations for each ratio and season were quite high, the summer and autumn value seemed to be largest at least in ultrafine region. 


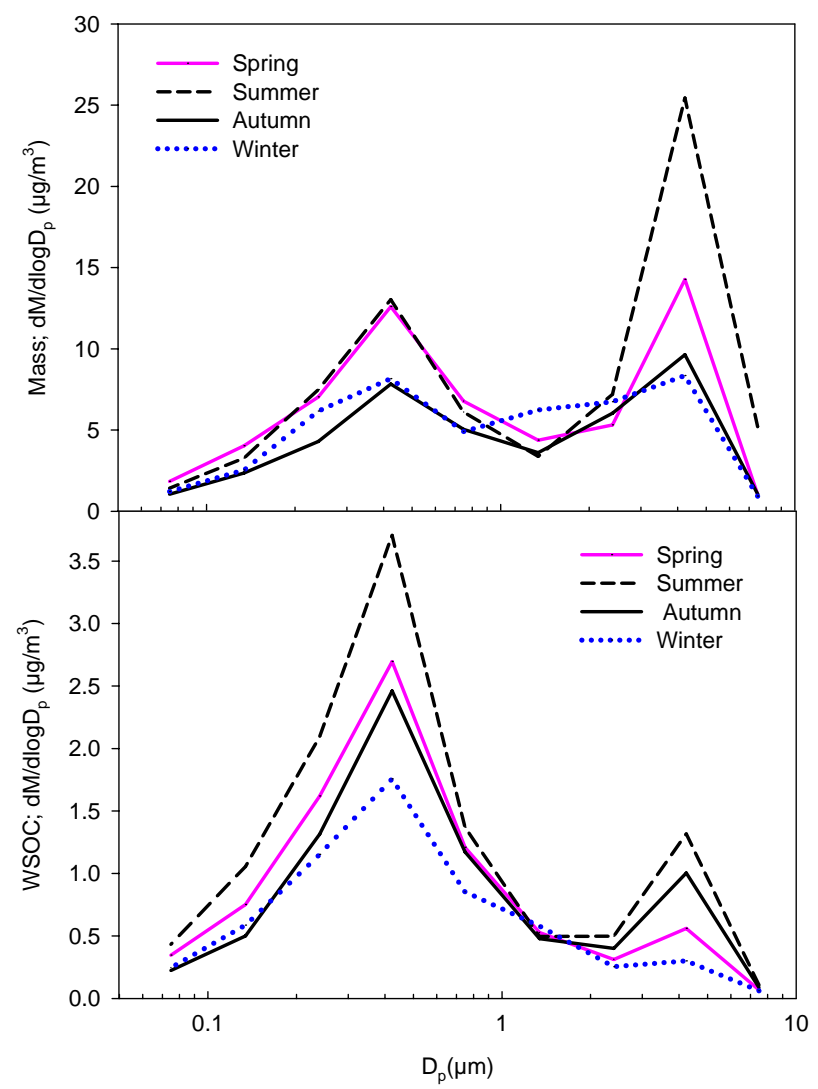

Fig. 2. The mass and WSOC size distributions for each season: spring (March-May), summer (June-August), autumn (SeptemberNovember), and winter (December-February).

Larger amount of WSPOM in summer is likely explained by increased photochemical and biogenic activity, the latter is valid also in early autumn. The photochemical activity is typically high in spring but the temperature was in March and April 2006 quite low and the biological activities might be insignificant. Most of the measurements done in May were excluded because of the wild fire episode. The high ratios at ultrafine particles also suggest that a considerable fraction of the measured particulate WSPOM may be of local or regional origin. According to literature, the most likely sources of the observed particulate WSPOM, especially in summer, are atmospheric oxidation processes, which may convert the biogenic and anthropogenic emissions of organic gases to a more water-soluble form (Fuzzi et al., 2006; Kanakidou et al., 2005).

\subsection{Seasonal differences in WSOC/OC ratios}

The averages of individual WSOC/OC ratios in submicrometer particles were calculated for each season. The WSOC was calculated from the MOUDI results as a sum of lowest stages with cut-size $\leq 1 \mu \mathrm{m}$ and $\mathrm{OC}$ was analyzed from the parallel collected $\mathrm{PM}_{1}$ filters. The WSOC/OC ratios measured

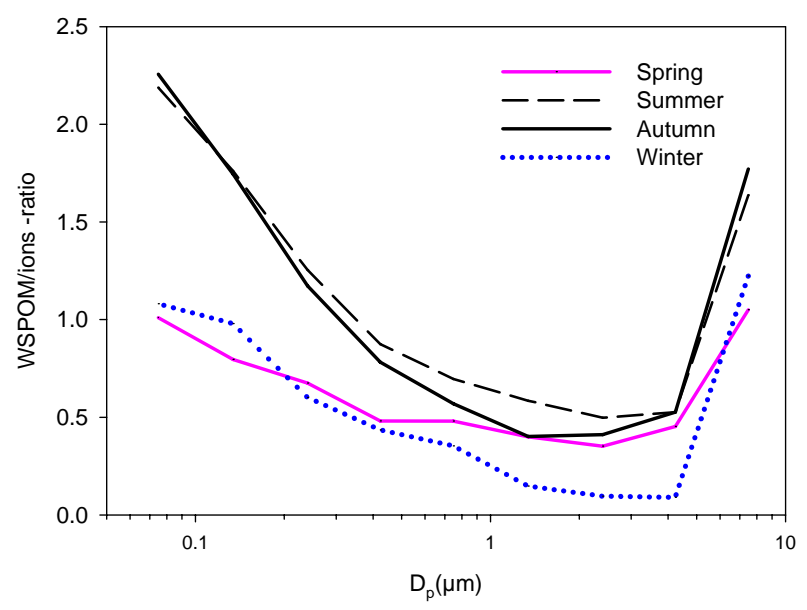

Fig. 3. The WSPOM/inorganic ions ratio in different size classes in MOUDI collections for each season: spring (March-May), summer (June-August), autumn (September-November), and winter (December-February). WSPOM=WSOC multiplied by 1.6.

during the biomass burning episode were excluded from the calculations of the seasonal WSOC/OC ratios. The lowest WSOC/OC ratio was observed in winter $(0.46 \pm 0.09)$ and the highest $(0.70 \pm 0.09)$ in summer. The WSOC/OC ratio was 0.53 in spring and autumn. The spring value had highest variation in WSOC/OC ratio (0.21-0.88) Comparable seasonal WSOC/OC ratios have been achieved in previous studies (e.g. Jaffrezo et al., 2005; Decesari et al., 2001). The higher WSOC/OC ratio suggests that the atmospheric conditions (oxidants, temperature, global radiation) in summer may favor the further oxidation of the organic compounds towards higher water-solubility. However, this is not the only explanation, because the source contributions will also change. The same trend has been observed in the aerosol mass spectrometer measurements in Tokyo (Kondo et al., 2007). Oxidation may also happen during cloud processing (Huang et al., 2006).

\subsection{WSOC source apportionment}

\subsubsection{Different sources and source areas of aerosol parti-} cles observed in Finland

In order to achieve a better understanding of the variability in the size-distributions of WSOC in the sample set, the samples were divided into five categories according to the air-mass back trajectories and according to the results of the gravimetric and chemical analysis. The categories were chosen to represent the most likely sources of particulate matter (PM) and WSOC in Finland. These include:

1. long-range transported (LRT) aerosols,

2. biomass burning aerosols originating from wild land fire episodes, 
Table 1. Gravimetric and chemical results, specific features and the air mass origin of five different sources.

\begin{tabular}{|c|c|c|c|c|c|c|}
\hline \multirow[b]{2}{*}{ Class } & \multicolumn{6}{|c|}{ Conc $\left(\mu \mathrm{g} \mathrm{m}^{-3}\right)$} \\
\hline & Known features & Mass & $\mathrm{SO}_{4}^{2-}$ & Levog. & $\begin{array}{l}\text { Seasalt/ } \\
\text { mass }^{\mathrm{a}}\end{array}$ & Air mass origin \\
\hline LRT $(n=4)$ & $\begin{array}{l}\text { High internal mixing } \\
\text { High mass concentration } \\
\text { Large accumulation mode } \\
\text { High } \mathrm{SO}_{4}^{2-} \text { concentration }\end{array}$ & 22.95 & 3.81 & 0.03 & 0.04 & $\begin{array}{l}\text { Continental areas of } \\
\text { Europe and Russia }\end{array}$ \\
\hline Wild land fires $(n=8)$ & $\begin{array}{l}\text { High levoglucosan conc. } \\
\text { Back-trajectories from the } \\
\text { areas of wild land fires }{ }^{b}\end{array}$ & 33.11 & 2.55 & 0.18 & 0.01 & $\begin{array}{l}\text { From known wild land } \\
\text { fires in Russia }\end{array}$ \\
\hline Clean $\operatorname{arctic}(n=7)$ & $\begin{array}{l}\text { Back-trajectories from arctic sea } \\
\text { Low mass concentration }\end{array}$ & 10.84 & 0.89 & 0.03 & 0.14 & From arctic sea \\
\hline Small-scale wood comb. $(n=5)$ & $\begin{array}{l}\text { Low temperature } \rightarrow \\
\text { increased domestic heating } \\
\text { High levoglucosan conc. }\end{array}$ & 12.38 & 2.67 & 0.11 & 0.15 & $\begin{array}{l}\text { From areas closer to } \\
\text { Finland }\end{array}$ \\
\hline Marine aerosols $(n=8)$ & $\begin{array}{l}\text { Back-trajectories } \\
\text { High } \mathrm{NaCl} \text { concentration } \\
\text { in coarse mode }\end{array}$ & 11.10 & 1.45 & 0.03 & 0.71 & From Baltic sea \\
\hline
\end{tabular}

a Seasalt defined as $3.248 *\left[\mathrm{Na}^{+}\right]$in coarse mode

b Saarikoski et al. (2006, 2007).

3. local small-scale wood combustion, aerosols in air masses from

4. clean arctic and

5. marine areas.

In Finland the anthropogenic emissions of fine particles and their precursor gases are low; the mean $\mathrm{PM}_{2.5}$ concentrations in 1999-2001 were typically only $9.6 \mu \mathrm{g} \mathrm{m}^{-3}$ at an urban site (Helsinki) and $5.8 \mu \mathrm{g} \mathrm{m}^{-3}$ at a rural background site (Hyytiälä; Laakso et al., 2003). In Helsinki typically 50$70 \%$ of the $\mathrm{PM}_{2.5}$ mass originates from LRT (Niemi et al., 2005). During the LRT pollution episodes, substantially elevated PM concentrations are typically measured (Niemi et al., 2004). Also the long-range transport of emissions from wild land fires from the Baltic countries, Belarus, Ukraine, and Russia raises the PM concentrations in Finland frequently during spring and summer (Niemi et al., 2004, 2005; Sillanpää et al., 2005b; Saarikoski et al., 2007). In a recent study of Saarikoski et al. (2008) one year $\mathrm{PM}_{1}$ data set from the location of this study was analysed for sources. Contribution of SOA was found to be very high during summer months, and wood combustion was most significant source during winter. Low PM concentrations with high sea salt concentrations are typically observed in Finland when the air masses originate from the direction of Arctic and Atlantic oceans (Pakkanen et al., 2001; Tunved et al., 2006). Tunved et al. (2006) also observed substantial gas-to-particle conversion in air masses undergoing marine to continental transition which was interpreted to be due to biogenic VOC emis- sions and subsequent SOA formation over the boreal forest in northern Europe. During winter, residential wood burning is a significant particulate emission source in northern Europe (Glasius et al., 2006; Frey et al., 2006). When the polluted air masses are influenced by biomass burning, such as smallscale combustion or wild land fires, very high levoglucosan mass concentrations are measured (Zdráhal et al., 2002; Sillanpää et al., 2005b; Yttri et al., 2005; Jordan et al., 2006; Saarikoski et al., 2007).

The chemical and gravimetric criteria of LRT in this study were elevated $\mathrm{SO}_{4}$ and mass concentrations. In addition to the enhanced levoglucosan concentration the wild fires were studied with help on satellite-based information and meteorological data. The local small-scale combustion was assumed to exist only in winter time with the elevated levoglucosan concentration. The biomass burning episodes were not occurred during winter time. The sea salt and mass concentrations and the ratio of sea salt to gravimetric mass together with back ward trajectories were used to categorize the different marine aerosols. 32 of the measured 45 MOUDI size distributions were placed in these categories. The classification remained unclear in 13 cases. The average mass, $\mathrm{SO}_{4}^{2-}$ and levoglucosan concentrations, average seasalt/mass ratios and air mass origin according to back-trajectories for the each class are presented in Table 1 . 
Table 2. The WSOC and OC concentrations $\left(\mu \mathrm{g} \mathrm{m}^{-3}\right)$ and WSOC/OC ratio in selected aerosol source categories.

\begin{tabular}{lllll}
\hline Source & $\begin{array}{l}\text { WSOC }\left(\mathrm{PM}_{1}\right) \\
(\text { average } \pm S D)\end{array}$ & $\begin{array}{l}\text { WSOC }\left(\mathrm{PM}_{1-10}\right) \\
(\text { average } \pm \mathrm{SD})\end{array}$ & $\begin{array}{l}\mathrm{OC}\left(\mathrm{PM}_{1}\right)^{\mathrm{a}} \\
(\text { average } \pm \mathrm{SD})\end{array}$ & $\begin{array}{l}\text { WSOC/OC } \\
(\text { average } \pm S D)\end{array}$ \\
\hline LRT & $2.0 \pm 0.72$ & $0.44 \pm 0.29$ & $2.5 \pm 0.40$ & $0.69 \pm 0.17$ \\
Wild land fires & $4.3 \pm 0.65$ & $0.71 \pm 0.23$ & $7.0 \pm 2.8$ & $0.64 \pm 0.06$ \\
Clean arctic & $0.58 \pm 1.0$ & $0.19 \pm 0.11$ & $1.3 \pm 0.64$ & $0.48 \pm 0.15$ \\
Small-scale wood combustion & $1.3 \pm 1.0$ & $0.25 \pm 0.19$ & $2.3 \pm 0.99$ & $0.49 \pm 0.13$ \\
Marine aerosols & $0.61 \pm 1.1$ & $0.19 \pm 0.09$ & $1.2 \pm 0.69$ & $0.53 \pm 0.12$ \\
\hline
\end{tabular}

${ }^{\mathrm{a}} \mathrm{OC}$ from the results of $\mathrm{PM}_{1}$ filter measurements

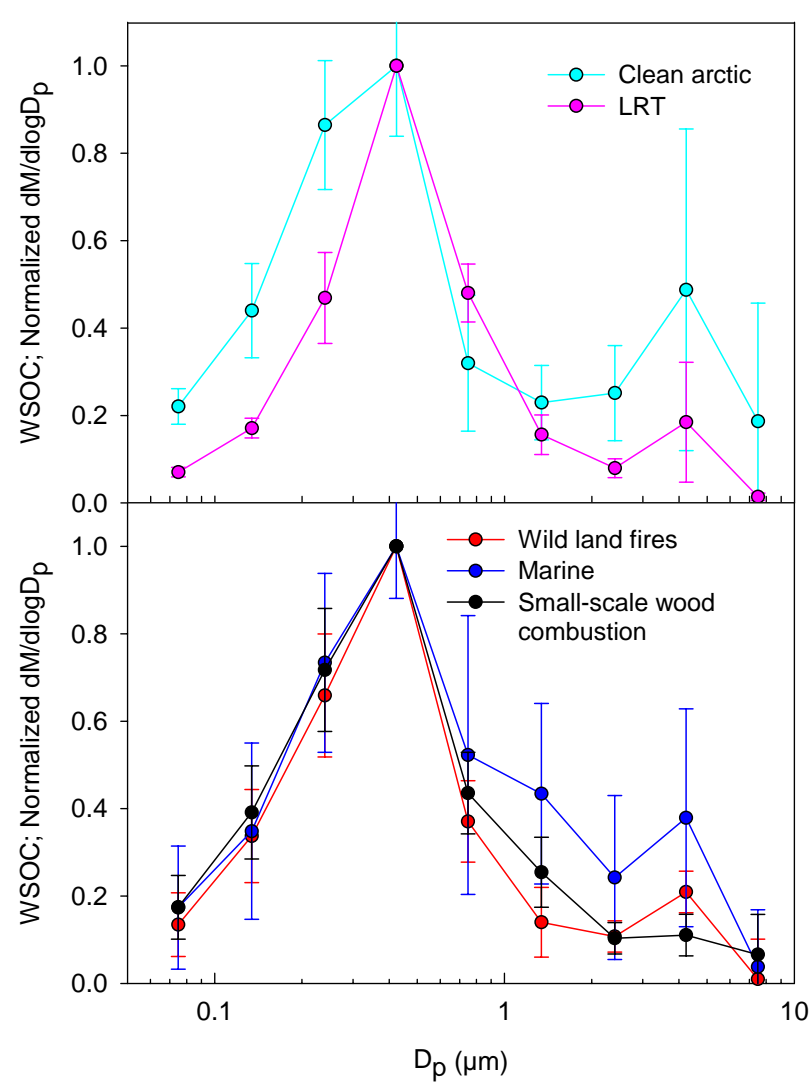

Fig. 4. The normalized WSOC size distributions representing the five different types of sampled air masses; LRT, clean arctic, wild land fires, marine and small-scale wood combustion.

3.5.2 Differences on WSOC concentrations and size distributions according to the origin of aerosol particles

Clear differences in the WSOC concentrations originating from the five different source categories (LRT, wild land fires, small-scale wood combustion, clean arctic, marine areas) were observed (Table 2), although the local conditions and sources of VOCs and aerosols as well as various transformation processes are likely to have an impact on the mea- sured aerosols composition. The amount of WSOC was largest when the particulate matter came from the wild land fire areas or was long-range transported. The WSOC concentrations were different in the two wild land fire episodes observed in spring and in summer. The observed WSOC concentrations were larger during the first episode in spring, 4.9-7.1 $\mu \mathrm{g} \mathrm{m}^{-3}$, whereas the measured WSOC concentrations varied in the range of $2-4.1 \mu \mathrm{g} \mathrm{m}^{-3}$ during the second episode in August. The lowest WSOC concentrations were measured in the air masses originating primarily from the clean arctic or marine areas.

The averages of individual WSOC/OC ratios in submicron particles were calculated for each source category. The WSOC was calculated from the MOUDI results as a sum of lowest stages with cut-size $\leq 1 \mu \mathrm{m}$ and OC was analyzed from the parallel collected $\mathrm{PM}_{1}$ filters. The calculated WSOC/OC ratios were different for the different source categories. The largest WSOC/OC ratios were observed in the case of the long-range transported aerosols originating from continental Europe $(0.83 \pm 0.07)$ and for the biomass burning aerosols originating from the areas of wild land fires $(0.64 \pm 0.06)$. This is probably explained by the atmospheric oxidation processes which increase the water-solubility of organic compounds during the long-range transport. The WSOC/OC ratios were almost equal for spring and summer biomass burning episodes, 0.64 and 0.63 , respectively. The smallest WSOC/OC ratios were observed in the aerosols affected by small-scale wood combustion $(0.49 \pm 0.13)$ which was expected to be local or regional. Small WSOC/OC ratios are typically observed near their sources (Pio et al., 2007). Small WSOC/OC ratios were observed also by Frey et al. (2006, WSOC/OC 0.3) in the small-scale wood combustion laboratory experiment.

The normalized WSOC size distributions (Fig. 4) for aerosols from different sources were clearly different. The size distribution of long-range transported WSOC was the narrowest and clearly most of the WSOC mass was observed in the accumulation mode. The size distributions of $\mathrm{SO}_{4}^{2-}$ (not shown) and WSOC had clearly a similar shape in LRT aerosols, and it was evident that most part of the WSOC was internally mixed with $\mathrm{SO}_{4}^{2-}$. The amount of the 
WSOC in ultrafine particles was very small. In the clean arctic air masses the normalized amount of WSOC in ultrafine particles was the largest $\left(0.21 \pm 0.04\right.$ for $D_{p}<0.056 \mu \mathrm{m}$ and $0.42 \pm 0.11$ for $\left.0.056<D_{p}<0.1 \mu \mathrm{m}\right)$. Recent studies indicate that this may be caused by the biogenic volatile organic compounds emitted by boreal forest condensing onto the existing ultrafine particles (Tunved et al., 2006; Anttila et al., 2007) during transport. Also the continuous formation of secondary organic aerosol from biogenic VOCs has been observed to take place during transport over forested areas (Tunved et al., 2006). The size distributions of WSOC in the air masses affected by the wild land fires and small-scale wood combustion were quite similar. The enrichment of WSOC into the ultrafine particles was also observed in the aerosols affected by the wild land fires $\left(0.13 \pm 0.05\right.$ for $D_{p}<0.056 \mu \mathrm{m}$ and $0.34 \pm 0.08$ for $\left.0.056<D_{p}<0.1 \mu \mathrm{m}\right)$ or by local smallscale wood combustion $\left(0.17 \pm 0.07\right.$ for $D_{p}<0.056 \mu \mathrm{m}$ and $0.39 \pm 0.11$ for $\left.0.056<D_{p}<0.1 \mu \mathrm{m}\right)$. For the aerosols originating from the marine areas the WSOC size distribution in ultrafine and accumulation mode was very similar to the size distributions of e.g. biomass burning but more WSOC was observed also in the coarse mode.

The size distribution of WSOC was compared to that of sodium (not shown) to establish whether the water-soluble compounds condense onto the sea-salt particles. Correlation between the size distributions was not found. This might be due to the fact that the coarse mode is a mixture of soilrelated and sea-salt particles, and WSOC might be condensing on both kinds of particles. The size distributions of calcium (not shown) and WSOC were compared to examine if water-soluble organic compounds are condensed on the soil-related particles. The size distributions of calcium and WSOC were clearly similar in the coarse mode, suggesting that the water-soluble organic compounds were associated with soil-related particles on the coarse mode rather than with sea-salt particles. Because particulate matter from soil itself usually contains WSOC, the contribution of this mechanism can not be assessed without additional organic speciation which was not available in this study.

To further examine the WSOC fraction, the ratios of WSPOM/mass and WSPOM/inorganic ions were calculated for the different aerosol sources for each size class. The $\mathrm{WSPOM} /$ mass ratio was in all cases largest in ultrafine particles (not shown) as it was in a case of different seasons. The amount of WSPOM was typically $15-38 \%$ of the measured total mass in the ultrafine particles. The WSPOM/mass ratio decreases as the particle size increases. The WSPOM in coarse mode accounted only $4-18 \%$ of the coarse particle mass. To exclude the effect of insoluble materials in the coarse particles, the WSPOM/ inorganic ions ratio was calculated for each size class. The largest WSPOM/inorganic ions ratios were observed in the ultrafine particles, where the amount of WSPOM exceeded the amount of inorganic ions. In the accumulation and coarse mode the amount of inorganic ions was larger than the amount of WSPOM.

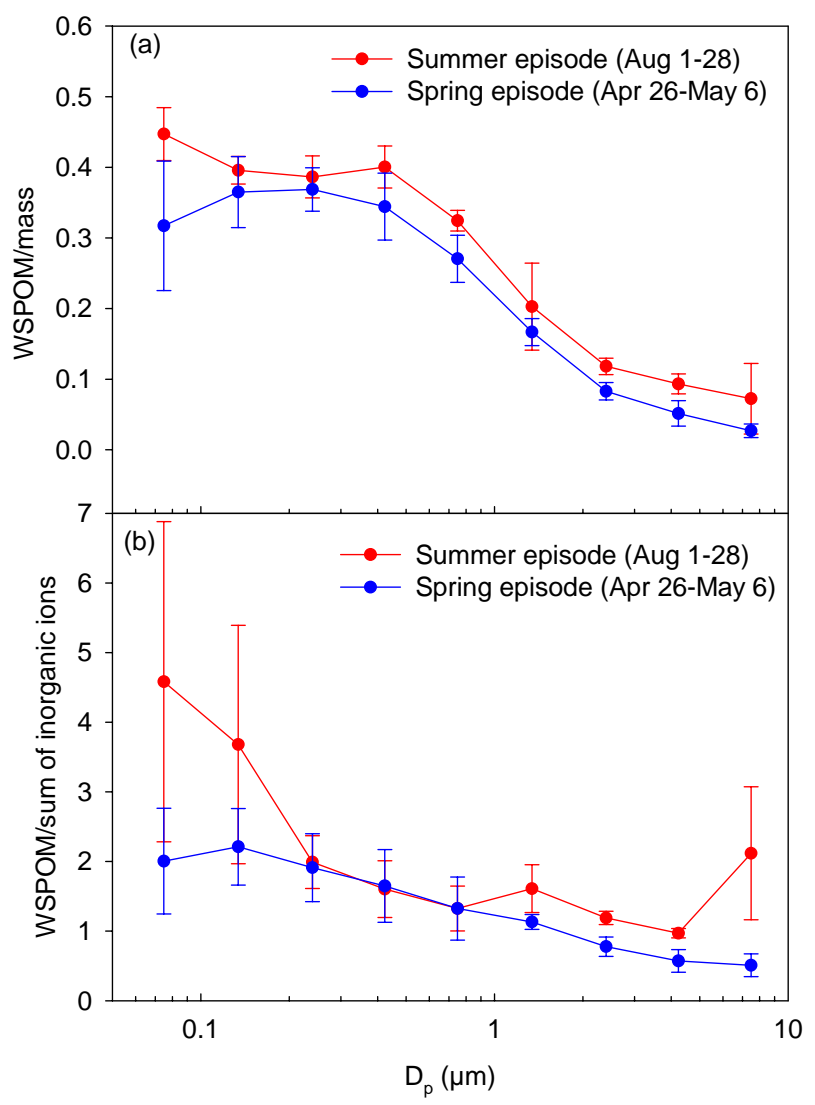

Fig. 5. The calculated WSPOM/mass ratio (a) and WSPOM/inorganic ions ratio (b) for biomass burning aerosols originating from the wild land fire areas in spring (26 April-6 May 2006) and in summer (1-28 August 2006). WSPOM=WSOC multiplied by 1.6 .

The enrichment of WSPOM into the ultrafine particles was observed in the biomass burning aerosols transported from the wild land fire areas (Fig. 5), where the WSPOM accounted for $29-38 \%$ of the measured total mass in ultrafine particles. The amount of WSPOM was larger than the amount of inorganic ions in all submicrometer particles for the aerosols originating from the wild land fire areas. The WSPOM/mass ratios were similar for both episodes (Fig. 5a), whereas the WSPOM/ions ratio in ultrafine particles was clearly larger and the range was wide in the second episode in August (Fig. 5b).

\subsubsection{The effect of biogenic VOCs on WSOC concentra- tions on different size classes}

In the recent studies it has been observed that continuous formation of secondary organic aerosol from biogenic VOCs takes place during transport over forested areas (Tunved et al., 2006). Some of the major oxidation products of biogenic VOCs have been observed to be water-soluble compounds (Cavalli et al, 2006; Kourtchev et al., 2005). Anttila 


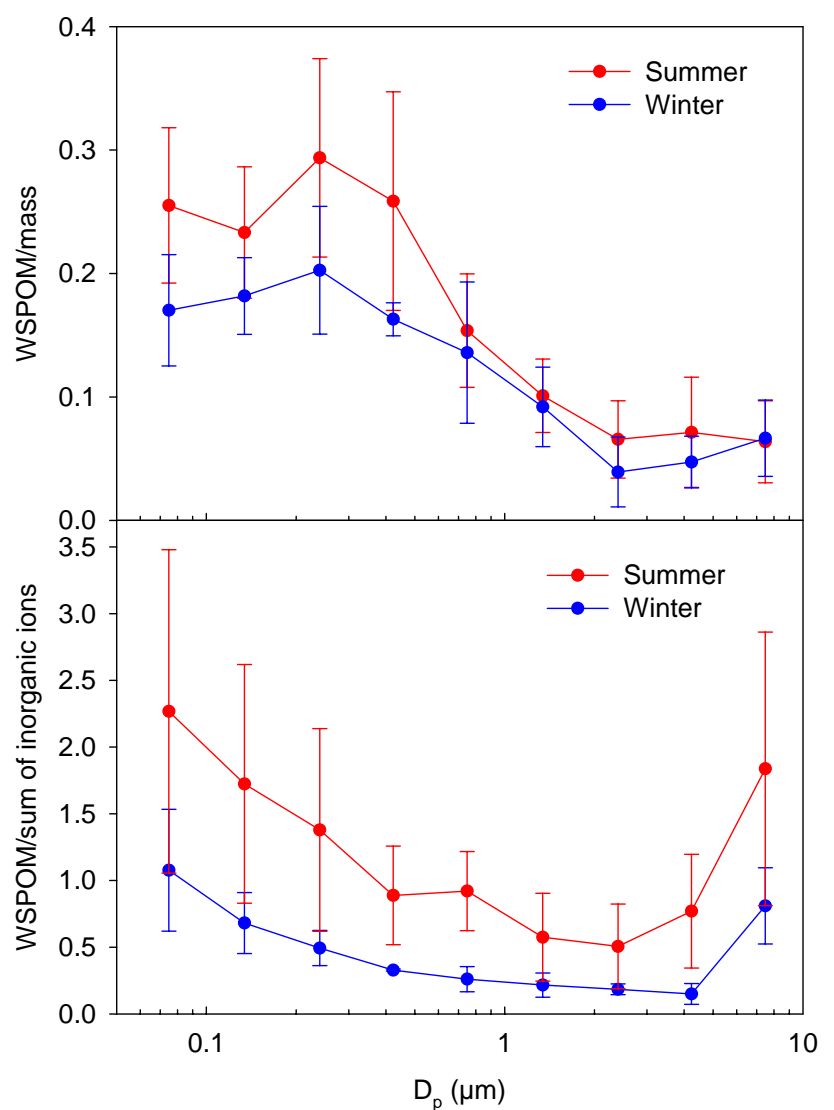

Fig. 6. The calculated WSPOM/mass ratio and WSPOM/inorganic ions ratio for aerosols originating from clean arctic areas in summer and in winter. WSPOM=WSOC multiplied by 1.6.

et al. (2007) has also observed the enrichment of monoterpene oxidation products into the smallest particles in chamber experiments. The WSOC size distributions measured from air masses originating from clean arctic areas were divided into two new categories, termed summer and winter measurements, to investigate the effect of biogenic VOCs on WSOC concentrations. The calculated WSPOM/mass and WSPOM/inorganic ions ratios for clean arctic air masses in summer and winter are represented in Fig. 6.

Figure 6 clearly shows that in the clean arctic air masses the amount of WSPOM in the ultrafine particles was larger in summer when the biogenic activity is high, when compared to winter. Also the WSPOM/inorganic ions ratio was clearly larger in the size distributions measured in summer. Figure 6 indicates that part of the biogenic VOCs condensing onto the pre-existing aerosol particles was most likely water-soluble or they were transformed to water-soluble compounds by oxidation after condensation. This is in agreement with previous findings in chamber experiments by Virkkula et al. (1999), who observed that the oxidation products of $\alpha$ pinene in the aerosol phase were slightly water-soluble. In the real atmosphere growth of ultrafine particles is due to e.g. condensation of both hygroscopic compounds (e.g. sulfuric acid) and the oxidation products of VOCs. The concentration of sulfuric acid does not completely explain the observed growth of ultrafine particles (Boy et al., 2005). Indirect methods have revealed that the water solubility of the newly formed particles in the boreal forest decreases as the particles grow toward larger sizes (Hämeri et al., 2001; Ehn et al., 2007), but they still remains slightly water soluble. Thus, considering the results of this study it is possible that the oxidation products from the biogenic VOCs contribute largely to the WSOC concentrations in the ultrafine particle size range during clean arctic air masses. However, at an urban background site, there are also several interfering anthropogenic sources, and strict conclusions of the role of natural sources are not possible without additional measurements.

\section{Summary and conclusions}

This paper presents the results of one-year-long measurements from February 2006 to 5 February 2007 of the size distributions of water-soluble organic carbon, ions and gravimetric mass concentrations at the urban background station (SMEAR III) in northern Europe boreal region in Finland. The WSOC, OC and MA concentrations were determined from the $\mathrm{PM}_{1}$ filter samples. The gravimetric mass concentrations $\left(\mathrm{PM}_{10}\right)$ in the MOUDI collections varied between 3.4 and $55 \mu \mathrm{g} \mathrm{m}^{-3}$. On average $25 \pm 7.7 \%$ of the aerosol $\mathrm{PM}_{1}$ mass and $7.5 \pm 3.4 \%$ of the $\mathrm{PM}_{1-10}$ mass comprised of watersoluble particulate organic matter (WSPOM $=1.6 \times$ WSOC). Inorganic ions contributed $33 \pm 12 \%$ and $28 \pm 19 \%$ of the analyzed $\mathrm{PM}_{1}$ and $\mathrm{PM}_{1-10}$ aerosol mass. The amount of inorganic ions in submicrometer particles was typically two times larger than the amount of WSPOM, except during the biomass burning episodes when the amount of WSPOM was substantially larger than the amount of inorganic ions.

The collected samples were classified into categories representing the most likely sources of particulate matter and WSOC in Finland. These include long-range transported aerosols, biomass burning aerosols originating from wild land fire episodes and local small-scale wood combustion and aerosols originating from clean arctic and marine areas. Clear differences in the WSOC concentrations and size distributions originating from different source areas were observed, demonstrating that the concentrations and the size distributions of WSOC are dependent on the source area and on the age of aerosol. Also large seasonal differences in the quantities were observed.

In summer the oxidation products of biogenic VOCs may increase WSOC concentrations, especially in the ultrafine particles, but at the urban measurements site also VOCs from other sources, and subsequent secondary aerosol formation are important contributors. Higher WSOC/mass and WSOC/OC ratios in summer indicate that the atmospheric oxidation processes are favoring the condensation of VOCs 
onto particles surfaces and that the atmospheric conditions are favoring the transformation of organic compounds toward higher water-solubility. The observed results support also the idea that the higher biogenic activity will increase condensation growth of aerosol particles and therefore increase the mass of WSOC (Kulmala et al., 2004).

During the large biomass burning episodes larger WSOC concentrations were measured. The enrichment of WSOC in ultrafine particles was observed in the aerosols originating from the wild land fire areas and local small scale combustion for residential heating. The small-scale combustion is a major source of WSOC in Finland in winter time, when the biogenic activity is very low. Larger WSOC/OC ratios were observed for aerosols originating from the wild land fires than for aerosols originating from the local small-scale combustion. This is likely caused by to the atmospheric oxidation processes which increase the water-solubility of the organic compounds during the transport.

During LRT episodes major part of aerosol mass is typically in the accumulation mode originating from various primary and secondary sources along the way to the measurement site, which may or may not have been cloud processed. Typically both condensation and cloud processing accumulate material to the accumulation mode as a function of time, which also explains enrichment of the WSOC into a accumulation mode. The size distributions of WSOC and sulphate were similar, suggesting that WSOC could be internally mixed with $\mathrm{SO}_{4}^{2-}$ in the LRT aerosols.

For aerosols originating from marine areas, the size distributions of sodium and WSOC in coarse mode were compared to see whether the WSOC is likely to condense on the surface of sea-salt particles. The size distributions of sodium and WSOC had clearly different shapes in the coarse mode. According to the results of this study it seems that over the continental area the water-soluble organic compounds in the coarse fraction are more likely associated with the soilrelated particles than with the sea-salt particles.

Acknowledgements. Financial support from the Graduate School in Physics, Chemistry, Biology and Meteorology of Atmospheric Composition and Climate Change (University of Helsinki), European Union (EUCAARI, Contract No: 036833) and the Maj and Tor Nessling foundation is gratefully acknowledged.

Edited by: A. Wiedensohler

\section{References}

Anttila, T., Kiendler-Scharr, A., Mentel, T. F., and Tillmann, R.: Size dependent partitioning of organic material: evidence for the formation of organic coatings on aqueous aerosols, J. Atmos. Chem., 57, 215-237, 2007.

Arp, H. P., Schwarzenbach, R. P., and Goss, K.: Equilibrium sorption of gaseous organic chemicals to fiber filters used for aerosol studies, Atmos. Environ., 41, 8241-8252, 2007.
Berner, A. and Lürzer, C.: Mass size distribution of traffic aerosols at Vienna, J. Phys. Chem., 84, 2079-2083, 1980.

Boy, M., Kulmala, M., Ruuskanen, T. M., Pihlatie, M., Reissell, A., Aalto, P. P., Keronen, P., Dal Maso, M., Hellen, H., Hakola, H., Jansson, R., Hanke, M., and Arnold, F.: Sulphuric acid closure and contribution to nucleation mode particle growth, Atmos. Chem. Phys., 5, 863-878, 2005,

http://www.atmos-chem-phys.net/5/863/2005/.

Cavalli, F., Facchini, M. C., Decesari, S., Emblico, L., Mircea, M., Jensen, N. R., and Fuzzi, S.: Size-segregated aerosol chemical composition at a boreal site in southern Finland, during the QUEST project, Atmos. Chem. Phys., 6, 993-1002, 2006, http://www.atmos-chem-phys.net/6/993/2006/.

Chan, A. W. H., Kroll, J. H., Ng, N. L., and Seinfeld, J. H.: Kinetic modeling of secondary organic aerosol formation: effects of particle- and gas-phase reactions of semivolatile products, Atmos. Chem. Phys., 7, 4135-4147, 2007, http://www.atmos-chem-phys.net/7/4135/2007/.

Decesari, S., Facchini, M. C., Matta, E., Lettini, F., Mircea, M., Fuzzi, S., Tagliavini, E., and Putaud, J.-P.: Chemical features and seasonal variation of fine aerosol water-soluble organic compounds in the Po Valley, Italy, Atmos. Environ., 35, 3691-3699, 2001.

Decesari, S., Facchini, M. C., Fuzzi, S., McFiggans, G. B., Coe, H., and Bower, K. N.: The water-soluble organic component of sizesegregated aerosol, cloud water and wet depositions from Jeju Island during ACE-Asia, Atmos. Environ., 39, 211-222, 2005.

Dye, C. and Yttri, K. E.: Determination of monosaccharide anhydrides in atmospheric aerosols by use of high-performance liquid chromatography combined with high-resolution mass spectrometry, Anal. Chem., 77, 1853-1858, 2005.

Ehn, M., Petäjä, T., Aufmhoff, H., Aalto, P., Hämeri, K., Arnold, F., Laaksonen, A., and Kulmala, M.: Hygroscopic properties of ultrafine aerosol particles in the boreal forest: diurnal variation, solubility and the influence of sulfuric acid, Atmos. Chem. Phys., 7, 211-222, 2007, http://www.atmos-chem-phys.net/7/211/2007/.

Frey, A., Virkkula, A., Saarnio, K., Timonen, H., TolonenKivimäki, O., Aurela, M., Hillamo, R., Tissari, J., Hytönen, K., Willman, P., Jokiniemi, J., Mannila, R., Saari, H., and Näkki, I.: Aerosol composition in fireplace emissions, Report series in aerosol science, 83, 325-329, 2006.

Fuzzi, S., Andreae, M. O., Huebert, B. J., Kulmala, M., Bond, T. C., Boy, M., Doherty, S. J., Guenther, A., Kanakidou, M., Kawamura, K., Kerminen, V.-M., Lohmann, U., Russell, L. M., and Pöschl, U.: Critical assessment of the current state of scientific knowledge, terminology, and research needs concerning the role of organic aerosols in the atmosphere, climate, and global change, Atmos. Chem. Phys., 6, 2017-2038, 2006, http://www.atmos-chem-phys.net/6/2017/2006/.

Glasius, M., Ketzel, M., Wåhlin, P., Jensen, B., Mønster, J., Berkowicz, R., and Palmgren, F.: Impact of wood combustion on particle levels in a residential area in Denmark, Atmos. Environ., 40, 7115-7124, 2006.

Hakola, H., Tarvainen, V., Laurila, T., Hiltunen, V., Hellen, H., and Keronen, P.: Seasonal variation of VOC concentrations above a boreal coniferous forest, Atmos. Environ., 37, 1623-1634, 2003.

Ho, K. F., Lee, S. C., Cao, J. J., Li, Y. S., Chow, J. C., Watson, J. G., and Fung, K.: Variability of organic and elemental carbon, wa- 
ter soluble organic carbon, and isotopes in Hong Kong, Atmos. Chem. Phys., 6, 4569-4576, 2006,

http://www.atmos-chem-phys.net/6/4569/2006/.

Huang, X.-F., Yu, J. Z., He, L.-Y., and Yuan, Z.: Watersoluble organic carbon and oxalate in aerosols at a coastal urban site in China: Size distribution characteristics, sources, and formation mechanisms, J. Geophys. Res., 111, D22212, doi:10.1029/2006JD007408, 2006.

Hämeri, K., Väkevä, M., Aalto, P. P., Kulmala, M., Swietlicki, E., Zhou, J., Seidl, W., Becker, E., and O'Dowd, C. D.: Hygroscopic and $\mathrm{CCN}$ properties of aerosol particles in boreal forests, Tellus B, 53, 359-379, 2001.

Jacobson, M. C., Hansson, H.-C., Noone, K. L., and Charlson, R. J.: Organic atmospheric aerosols: review and state of the science, Rev. Geophys., 38, 267-294, 2000.

Jaffrezo, J.-L., Aymoz, G., Delaval, C., and Cozic, J.: Seasonal variations of the water soluble organic carbon mass fraction of aerosol in two valleys of the French Alps, Atmos. Chem. Phys., 5, 2809-2821, 2005, http://www.atmos-chem-phys.net/5/2809/2005/.

Jordan, T. B., Seen, A. J., and Jacobsen, G. E.: Levoglucosan as an atmospheric tracer for wood smoke, Atmos. Environ., 40, 53165321, 2006.

Kanakidou, M., Seinfeld, J. H., Pandis, S. N., Barnes, I., Dentener, F. J., Facchini, M. C., Van Dingenen, R., Ervens, B., Nenes, A., Nielsen, C. J., Swietlicki, E., Putaud, J. P., Balkanski, Y., Fuzzi, S., Horth, J., Moortgat, G. K., Winterhalter, R., Myhre, C. E. L., Tsigaridis, K., Vignati, E., Stephanou, E. G., and Wilson, J.: Organic aerosol and global climate modelling: a review, Atmos. Chem. Phys., 5, 1053-1123, 2005,

http://www.atmos-chem-phys.net/5/1053/2005/.

Kondo, Y., Miyazaki, Y., Takegawa, N., Miyakawa, T., Weber, R. J., Jimenez, J. L., Zhang, Q., and Worsnop, D. R.: Oxygenated and water-soluble organic aerosols in Tokyo, J. Geophys. Res., 112, D011203, doi:10.1029/2006JD007056, 2007.

Kourtchev, I., Ruuskanen, T., Maenhaut, W., Kulmala, M., and Claeys, M.: Observation of 2-methyltetrols and related photooxidation products of isoprene in boreal forest aerosols from Hyytiälä, Finland, Atmos. Chem. Phys., 5, 2761-2770, 2005, http://www.atmos-chem-phys.net/5/2761/2005/.

Kulmala, M., Suni, T., Lehtinen, K. E. J., Dal Maso, M., Boy, M., Reissell, A., Rannik, Ü., Aalto, P., Keronen, P., Hakola, H., Bäck, J., Hoffmann, T., Vesala, T., and Hari, P.: A new feedback mechanism linking forests, aerosols, and climate, Atmos. Chem. Phys., 4, 557-562, 2004, http://www.atmos-chem-phys.net/4/557/2004/.

Laakso, L., Hussein, T., Aarnio, P., Komppula, M., Hiltunen, V., Viisanen, Y., and Kulmala, M.: Diurnal and annual characteristics of particle mass and number concentrations in urban, rural and Arctic environments in Finland, Atmos. Environ., 37, 26292641, 2003.

Li, S.-M., Tang, J., Xue, H., and Toom-Sauntry, D.: Sizedistribution and Estimated optical properties of carbonate, water soluble organic carbon, and sulfate in aerosols at a remote high altitude site in Western China, Geophys. Res. Lett., 27, 11071110, 2000.

Liu, B. Y. and Pui, D. Y.: Aerosol sampling inlets and inhalable particles. Atmos. Environ., 15, 585-600, 1981.

Marple, V. A., Rubow, K. L., and Behm, S. M.: A Microorifice Uni- form Deposit Impactor (MOUDI): Description, calibration and use, Aerosol Sci. Tech., 14, 434-446, 1991.

Matta, E., Facchini, M. C., Decesari, S., Mircea, M., Cavalli, F., Fuzzi, S., Putaud, J.-P., and DellAcqua, A.: Mass closure on the chemical species in size-segregated atmospheric aerosol collected in an urban area of the Po Valley, Italy, Atmos. Chem. Phys., 3, 623-637, 2003, http://www.atmos-chem-phys.net/3/623/2003/.

Niemi, J. V., Tervahattu, H., Vehkamäki, H., Kulmala, M., Koskentalo, T., Sillanpää, M., and Rantamäki, M.: Characterization and source identification of a fine particle episode in Finland, Atmos. Environ., 38, 5003-5012, 2004.

Niemi, J. V., Tervahattu, H., Vehkamäki, H., Martikainen, J., Laakso, L., Kulmala, M., Aarnio, P., Koskentalo, T., Sillanpää, M., and Makkonen, U.: Characterization of aerosol particle episodes in Finland caused by wildfires in Eastern Europe, Atmos. Chem. Phys., 5, 2299-2310, 2005, http://www.atmos-chem-phys.net/5/2299/2005/.

Pakkanen, T. A., Loukkola, K., Korhonen, C. H., Aurela M., Mäkelä, T., Hillamo, R., Aarnio, P., Koskentalo, T., Kousa, A., and Maenhaut, W.: Sources and chemical composition of atmospheric fine and coarse particles in the Helsinki area, Atmos. Environ., 35, 5381-5391, 2001.

Pio, C. A., Legrand, M., Oliveira,T., Afonso, J., Santos, C., Caseiro, A., Fialho, P., Barata, F., Puxbaum, H., Sanchez-Ochoa, A., Kasper-Giebl, A., Gelencsér, A., Preunkert, S., and Schock, M.: Climatology of aerosol composition (organic versus inorganic) at nonurban sites on a west-east transect across Europe, J. Geophys. Res., 112, D23S02, doi:10.1029/2006JD008038, 2007.

Saarikoski, S., Sillanpää, M., Saarnio, K., Timonen, H., Teinilä, K., and Hillamo, R.: Chemical composition of fine particles in major burning episodes observed in Finland in 2006, Report series in aerosol science, 83, 325-329, 2006.

Saarikoski, S., Sillanpää, M., Sofiev, M., Timonen, H., Saarnio, K., Teinilä, K., Karppinen, A., Kukkonen, J., and Hillamo, R.: Chemical composition of aerosols during a major biomass burning episode over northern Europe in spring 2006: Experimental and modeling assessments, Atmos. Environ., 41, 3577-3589, 2007.

Saarikoski, S., Timonen, H., Saarnio, K., Aurela, M., Järvi, L., Keronen, P., Kerminen, V.-M., and Hillamo, R.: Sources of organic carbon in $\mathrm{PM}_{1}$ in Helsinki urban air, Atmos. Chem. Phys. Discuss., 8, 7805-7846, 2008, http://www.atmos-chem-phys-discuss.net/8/7805/2008/.

Sillanpää, M., Frey, A., Hillamo, R., Pennanen, A. S., and Salonen, R. O.: Organic, elemental and inorganic carbon in particulate matter of six urban environments in Europe, Atmos. Chem. Phys., 5, 2869-2879, 2005

Sillanpää, M., Saarikoski, S., Hillamo, R., Pennanen, A., Makkonen, U., Spolnik, U., Van Grieken, R., Koskentalo, T., and Salonen, R. O.: Chemical composition, mass size distribution and source analysis of long-range transported wildfire smokes in Helsinki, Sci. Total Environ., 350, 119-135, 2005.

Stohl, A. and Wotawa, G.: A method for computing single trajectories representing boundary layer transport, Atmos. Environ., 29, 3235-3239, 1995.

Subramanian, R., Khlystov, A. Y., and Robinson, A. L.: Effect of Peak Inert-Mode Temperature on Elemental Carbon Measured Using Thermal-Optical Analysis, Aerosol Sci. Tech., 40, 763- 
780, 2006.

Timonen, H. J., Saarikoski, S. K., Aurela, M. A., Saarnio, K. M., and Hillamo, R. E. J.: Water-soluble organic carbon in urban aerosol: concentrations, size distributions and contribution to particulate matter, Boreal Environ. Res., 13, 335-346, 2008.

Turpin, B. J. and Lim, H.-J.: Species contributions to PM $_{2.5}$ mass concentrations: revisiting common assumptions for estimating organic mass, Aerosol Sci. Tech., 35, 602-610, 2001.

Tunved, P., Hansson, H.-C., Kerminen, V.-M., Ström, J., Dal Maso, M., Lihavainen, H., Viisanen, Y., Aalto, P. P., Komppula, M., and Kulmala, M.: High natural aerosol loading over boreal forests, Science, 312, 261-263, 2006.

Turšič, J., Podkrajšek, B., Grgic, I., Ctyroky, P., Berner, A., Dusek, U., and Hitzenberger, R.: Chemical composition and hygroscopic properties of size-segregated aerosol particles collected at the Adriatic coast of Slovenia, Chemosphere, 63, 1193-1202, 2006.

Viana, M., Chi X., Maenhaut, W., Querol, A., Alastuey, A., Mikuska, P., and Vecera, Z.: Organic and elemental carbon concentrations in carbonaceous aerosols during summer and winter sampling campaigns in Barcelona, Spain, Atmos. Environ., 40, 2180-2193, 2006.

Viidanoja, J., Sillanpää, M., Laakia, J., Kerminen, V.-M., Hillamo, R., Aarnio, P., and Koskentalo, T.: Organic and black carbon in $\mathrm{PM}_{2.5}$ and $\mathrm{PM}_{10}$ : 1 year of data from an urban site in Helsinki, Finland, Atmos. Environ., 36, 3183-3193, 2002.

Virkkula, A., Van Dingenen, R., Raes, F., and Hjort, J.: Hygroscopic properties of aerosol formed by oxidation of limonene, alpha-pinene, and beta-pinene, J. Geophys. Res., 104(D3), 35693580, 1999.
Weber, R. J., Sullivan, A. P., Peltier, R. E., Russell, A., Yan, B., Zheng, M., de Gouw, J., Warneke, C., Brock, C., Holloway, J. S., Atlas, E. L., and Edgerton, E.: A study of secondary organic aerosol formation in the anthropogenicinfluenced southeastern United States, J. Geophys. Res., 112, D13302, doi:10.1029/2007JD008408, 2007.

Yao, X., Fang, M., and Chan, C. K.: Size distributions and formation of dicarboxylic acids in atmospheric particles, Atmos. Environ., 36, 2099-2107, 2002.

Yoon, Y. J., Ceburnis, D., Cavalli, F., Jourdan, O., Putaud, J. P., Facchini, M. C., Decesari, S., Fuzzi, S., Sellegri, K., Jennings, S. G., and O'Dowd, C. D.: Seasonal characteristics of the physicochemical properties of North Atlantic marine atmospheric aerosols, J. Geophys. Res., 112, D04206, doi:10.1029/2005JD007044, 2007.

Yu, J. Z., Yang, H., Zhang, H., and Lau, A. K. H.: Size distributions of water-soluble organic carbon in ambient aerosols and its size-resolved thermal characteristics, Atmos. Environ., 38, 1061-1071, 2004.

Yttri, K. E., Dye, C., Slødal, L. H., and Braathen, O.-A.: Quantification of monosaccharide anhydrides by liquid chromatography combined with mass spectrometry: application to aerosol samples from an urban and a suburban site influenced by small-scale wood burning, J. Air Waste Manage., 55, 1169-1177, 2005.

Zdráhal, Z., Oliveira, J., Vermeylen, R., Claeys, M., and Maenhaut, W.: Improved method for quantifying levoglucosan and related monosaccharide anhydrides in atmospheric aerosols and application to samples from urban and tropical locations, Environ. Sci. Technol., 36, 747-753, 2002. 